\title{
Analysis of Xq27-28 linkage in the international consortium for prostate cancer genetics (ICPCG) families
}

Joan E Bailey-Wilson 1,7,32*, Erica J Childs ${ }^{1,2}$, Cheryl D Cropp ${ }^{1}$, Daniel J Schaid ${ }^{3}$, Jianfeng Xu ${ }^{4}$, Nicola J Camp ${ }^{5}$, Lisa A Cannon-Albright ${ }^{5,6}$, James M Farnham5, Asha George ${ }^{1,7,8}$, Isaac Powell ${ }^{7,9}$, John D Carpten ${ }^{7,10}$, Graham G Giles ${ }^{11,12,13}$, John L Hopper ${ }^{11,13}$, Gianluca Severi ${ }^{11,12,13}$, Dallas R English 11,12,13. William D Foulkes ${ }^{11,14}$, Lovise Mæhle ${ }^{11,15}$, Pål Møller ${ }^{11,15}$, Rosalind Eeles ${ }^{11,16}$, Douglas Easton ${ }^{11,17}$, Michelle Guy ${ }^{11,16}$, Steve Edwards ${ }^{11,16}$, Michael D Badzioch ${ }^{11,18}$, Alice S Whittemore 19,20,21, Ingrid Oakley-Girvan 19,20,21,42, Chih-Lin Hsieh ${ }^{19,22}$, Latchezar Dimitrov 4 , Janet L Stanford ${ }^{23,24}$, Danielle M Karyadi ${ }^{23,25}$, Kerry Deutsch ${ }^{23,26}$, Laura McIntosh ${ }^{23,24}$, Elaine A Ostrander ${ }^{23,25}$, Kathleen E Wiley ${ }^{27}$, Sarah D Isaacs ${ }^{27}$, Patrick C Walsh ${ }^{27}$, Stephen N Thibodeau ${ }^{28,}$ Shannon K McDonnell ${ }^{28}$, Scott Hebbring ${ }^{28}$, Ethan M Lange ${ }^{29,30}$, Kathleen A Cooney ${ }^{29,31}$, Teuvo LJ Tammela ${ }^{32,33,34}$, Johanna Schleutker ${ }^{32,33,34}$, Christiane Maier ${ }^{35,36,37}$, Sylvia Bochum ${ }^{35,37}$, Josef Hoegel ${ }^{35,37}$, Henrik Grönberg ${ }^{38}$, Fredrik Wiklund ${ }^{38}$, Monica Emanuelsson ${ }^{39}$, Geraldine Cancel-Tassin ${ }^{40}$, Antoine Valeri4 ${ }^{40}$, Olivier Cussenot ${ }^{40,41}$, William B Isaacs ${ }^{27}$ and the International Consortium for Prostate Cancer Genetics

\begin{abstract}
Background: Genetic variants are likely to contribute to a portion of prostate cancer risk. Full elucidation of the genetic etiology of prostate cancer is difficult because of incomplete penetrance and genetic and phenotypic heterogeneity. Current evidence suggests that genetic linkage to prostate cancer has been found on several chromosomes including the $X_{\text {; }}$ however, identification of causative genes has been elusive.
\end{abstract}

Methods: Parametric and non-parametric linkage analyses were performed using 26 microsatellite markers in each of 11 groups of multiple-case prostate cancer families from the International Consortium for Prostate Cancer Genetics (ICPCG). Meta-analyses of the resultant family-specific linkage statistics across the entire 1,323 families and in several predefined subsets were then performed.

Results: Meta-analyses of linkage statistics resulted in a maximum parametric heterogeneity lod score (HLOD) of 1.28 , and an allele-sharing lod score (LOD) of 2.0 in favor of linkage to Xq27-q28 at $138 \mathrm{cM}$. In subset analyses, families with average age at onset less than 65 years exhibited a maximum HLOD of 1.8 (at $138 \mathrm{cM}$ ) versus a maximum regional HLOD of only 0.32 in families with average age at onset of 65 years or older. Surprisingly, the subset of families with only 2-3 affected men and some evidence of male-to-male transmission of prostate cancer gave the strongest evidence of linkage to the region ( $\mathrm{HLOD}=3.24,134 \mathrm{CM}$ ). For this subset, the HLOD was slightly increased $(H L O D=3.47$ at $134 \mathrm{CM}$ ) when families used in the original published report of linkage to Xq27-28 were excluded.

(Continued on next page)

\footnotetext{
* Correspondence: jebw@mail.nih.gov

${ }^{1}$ Inherited Disease Research Branch, National Human Genome Research Institute, National Institutes of Health, Baltimore MD 21224, USA

${ }^{7}$ African American Hereditary Prostate Cancer ICPCG Group, Phoenix AZ, USA

Full list of author information is available at the end of the article
} 
(Continued from previous page)

Conclusions: Although there was not strong support for linkage to the Xq27-28 region in the complete set of families, the subset of families with earlier age at onset exhibited more evidence of linkage than families with later onset of disease. A subset of families with 2-3 affected individuals and with some evidence of male to male disease transmission showed stronger linkage signals. Our results suggest that the genetic basis for prostate cancer in our families is much more complex than a single susceptibility locus on the X chromosome, and that future explorations of the $\mathrm{Xq} 27-28$ region should focus on the subset of families identified here with the strongest evidence of linkage to this region.

\section{Background}

Prostate cancer (PC) is the most common male cancer in developed countries [1]. In the United States, each year there are over 200,000 newly diagnosed cases and over 30,000 deaths attributable to prostate cancer [2]. Family history, along with older age and AfricanAmerican ancestry, are the most important risk factors established to date. Inherited genetic factors might account for a proportion of the familial risk, but it has been very difficult to discover the actual genetic basis of prostate cancer probably due to the large number of loci involved, the incomplete and possibly low penetrance associated with these loci, and the likely clinical and genetic heterogeneity of this disease.

In 1996, the first prostate cancer linkage report implicated chromosome 1q23-25 [3], but subsequent linkage studies have found contradictory conclusions. In this same year the International Consortium for Prostate Cancer Genetics (ICPCG), consisting of researchers from 11 groups around the world, was formed. With the initial aim of examining linkage and trying to replicate previous linkage findings the ICPCG pooled 1,323 pedigrees with clinically- (but not genetically-) defined "hereditary prostate cancer" (HPC). Given the large number of families in this dataset, it was hoped that this would provide increased power to confirm or exclude linkage, and to allow for informative linkage analyses of large homogeneous subsets in an attempt to control for some of the likely heterogeneity that would otherwise weaken the ability to detect linkage. The ICPCG analysis of 775 families supported the finding of a prostate cancersusceptibility gene linked to 1q24-25 in a defined subset of prostate cancer families with early age at onset, at least 5 affected relatives and evidence of male-to-male transmission [4]. The RNASEL gene was later implicated as harboring rare variant alleles that increase risk of prostate cancer and may account for this linkage signal [5]. Evidence has been accumulating in support of RNASEL as a prostate cancer risk locus, with several recent large case-control and cohort studies and a very large meta-analysis all showing significant associations of prostate cancer risk with polymorphisms in this locus [6-10].
Several other susceptibility loci presumed to contain rare variants of large effect on individual risk of prostate cancer have been suggested [3,4,11-42] and reviewed elsewhere [30,41,42]. In addition, recent genome-wide association studies (GWAS) have implicated multiple loci at which there are common variants (single nucleotide polymorphisms; SNPs) that are not necessarily functional but are associated with small effects on individual risk of prostate cancer [43-49]. For a review see Varghese and Easton [50]. Work is proceeding to try to identify more susceptibility loci, by GWAS using common SNP risk alleles, by conventional linkage analyses aimed at detecting genes with rare, high-penetrance risk alleles and by whole exome and whole genome sequencing analyses that can be used in conjunction with linkage and GWAS results.

In 1998, a study of 360 multiple-case families found evidence for a prostate cancer susceptibility locus on chromosome $\mathrm{X}$ in the region Xq27-q28 (HPCX) [38]. A subset of 52 Finnish families from this study was used to examine whether phenotypic subsets of families exhibited different evidence for linkage to this region. This study showed that families with no male-to-male (NMM) transmission and late age of onset of prostate cancer ( $>65$ years) exhibited stronger evidence of linkage to the $\mathrm{Xq} 27-28$ region than did the complete set of families [33]. There have been five replication studies, four of which supported linkage of prostate cancer susceptibility to this region [6,21,51-53] with the study of large Utah pedigrees yielding independent genome-wide significant evidence of linkage [21], and one which did not support linkage to this region [12]. A fine-mapping study in the Finnish population examined association of prostate cancer to microsatellite markers in the HPCX Xq27-28 region using 108 independent prostate cancer patients selected from families with multiple affected men (55 were from the linkage study above) and 257 controls (anonymous, healthy male blood donors) from the same Finnish population. Significant association was observed for two markers in the region, DXS1205 $(\mathrm{p}=0.0003)$ and bG82i1.1 $(\mathrm{p}=0.0006)$, with stronger association observed at DXS1205 in the subset of 60 cases from families with no evidence of male-to-male 
transmission $(p=0.0002)$ [11]. Association of these two markers with prostate cancer risk has been replicated in an Ashkenazi Jewish founder population [6]. Positive associations were observed for allele 135 of the bG82i1.1 marker $(\mathrm{OR}=1.77, \mathrm{P}=0.01)$ and allele 188 of DXS1205 $(\mathrm{OR}=1.65, \mathrm{P}=0.02)$ in 979 prostate cancer cases and 1,251 controls.

Under the Xq27-q28 linkage peak is a region of $\sim 750 \mathrm{~kb}$ containing five SPANX genes (SPANX-A1, -A2, $-B,-C$, and $-D$ ). The SPANX genes encode nucleusassociated sperm proteins and their expression has been detected in a variety of cancers. While they were originally suggested as candidate genes for the $H P C X$ susceptibility locus [54], more recent work has found no association between prostate cancer and mutations in any of these genes [55]. However, a more complex involvement of these genes is possible. Putative candidate genes for association with prostate cancer have been found on other regions of the $\mathrm{X}$ chromosome.

Gudmundsson et al. conducted a genome-wide SNP association study of prostate cancer in over 23,000 Icelanders followed by a separate replication study. Of the two novel SNPs identified by this study, one, rs5945572, was found on XP11.22 (odds ratio $(\mathrm{OR})=1.23$ ) [56]. Eeles et al. also found association to this region in a large GWAS [47]. However, the odds ratios for the risk genotypes at this putative locus are quite small and not likely to be responsible for the linkage signal observed on $\mathrm{Xq}$ in highly aggregated pedigrees.

The aims of this study were to examine the evidence for linkage of prostate cancer to chromosome X using 1,323 multiple-case prostate cancer families from the ICPCG and genotyping a consensus map of 25 microsatellite markers and using both parametric and nonparametric allele-sharing linkage analyses. The pedigree subsets evaluated were presence/absence of male-tomale disease transmission (a surrogate for X-linked inheritance), Carter criteria of HPC [57,58], average age at onset of affected men in the family $(<65$ years of age or $\geq 65$ years), and number of men in a family with confirmed PC. Determining whether any of these subsets show stronger evidence of linkage to the region may guide the selection of cases for future mutational analysis in this region.

\section{Methods}

This analysis was performed on 1,323 families with hereditary prostate cancer ascertained by 11 groups participating in the ICPCG. The process of ascertaining families and confirming diagnosis of prostate cancer differed among the groups, but in all samples, men were considered to be affected with prostate cancer only if medical records or death certificates could confirm the diagnosis. The 11 groups that participated in this linkage analysis are described elsewhere [59].

In the statistical analysis, all families were first analyzed together. In addition, several subsets of families were created based on pedigree characteristics. A pedigree was classified as satisfying the Carter criteria for hereditary prostate cancer $[57,58]$ if at least one of the following conditions were met: 1) three consecutive generations of $\mathrm{PC}$ along a line of descent; 2) at least three first-degree relatives with a diagnosis of $\mathrm{PC}$; 3 ) two or more relatives with a diagnosis of $\mathrm{PC}$ at age $\leq 55$ years. Pedigrees were also classified according to whether transmission of $\mathrm{PC}$ in the family appeared consistent with $\mathrm{X}$-linked transmission (yes versus no versus unclear). A pedigree was considered to be consistent with $\mathrm{X}$-linked transmission if all affected males only had a family history of prostate cancer on the maternal side of the family so there was no evidence of male-to-male transmission of a prostate cancer risk allele. A pedigree was considered to be inconsistent with X-transmission if the family contained at least one affected father-affected son pair or if at least one affected son had an affected paternal uncle or paternal grandfather (male-to-male transmission). Pedigrees containing at least one male who had a family history of prostate cancer on both sides of his family (bilineal) were considered to be inconsistent with $\mathrm{X}$-transmission. Pedigrees containing only a sibship of affected men with no information about the prostate cancer history on the maternal or paternal sides of the family were considered to be unclear for Xtransmission. Pedigrees were also classified as to whether or not the average age at onset of affected men in the family was less than 65 years of age.

Each group had genotyped a different set of markers in the Xq27-q28 region. In order to use the available genotype data without re-genotyping a common panel of markers, a consensus map of the genetic markers from the different groups was created as follows. A total of 26 different markers on chromosome Xq (see Additional file 1: Table S1) were genotyped by ICPCG members. For our analysis, the order of these markers was determined from UCSC Goldenpath (version hg13, released Nov.14.2002). The marker distance was based on the deCode map [60]. All markers were successfully mapped to Goldenpath or deCode maps and cM distances were interpolated for some markers that were located on Goldenpath but not on the deCode map (Table 1). Because some groups did not have either the first or last markers from this consensus map, dummy noninformative markers (i.e., homozygous for all subjects) were used as anchors for these groups. This allowed us to align all group's linkage files to the consensus map, allowing for different groups using different markers. All groups computed parametric multipoint LOD scores 
Table 1 Markers used in the analysis with map location information (base pair locations from the UCSC Goldenpath version hg13, released Nov.14.2002 and cM locations from the deCode linkage map)

\begin{tabular}{|c|c|c|c|c|}
\hline Marker & bp Start & bp End & deCode cM Position & interpolated $\mathrm{cM}$ position \\
\hline DXS1216 & 66597577 & 66597945 & 82.98 & 82.98 \\
\hline DXS6800 & 76721582 & 76721893 & 86.84 & 86.84 \\
\hline DXS986 & 77422288 & 77422628 & 86.84 & 86.84 \\
\hline DXS990 & 91036325 & 91036548 & 94.92 & 94.92 \\
\hline DXS6789 & 93484970 & 93485285 & 96.95 & 96.95 \\
\hline DXS1106 & 100764898 & 100765284 & & 101.56 \\
\hline DXS6797 & 105514006 & 105514365 & 104.57 & 104.57 \\
\hline GATA172D05 & 111199673 & 111199793 & 110.42 & 110.42 \\
\hline DXS8055 & 112690834 & 112691203 & & 112.66 \\
\hline DXS1001 & 117811961 & 117812315 & 120.35 & 120.35 \\
\hline GATA165B12 & 118830243 & 118830577 & 122.11 & 122.11 \\
\hline DXS1047 & 127020308 & 127020598 & & 131.44 \\
\hline DXS1192 & 136312813 & 136313015 & 142.03 & 142.03 \\
\hline DXS1232 & 137224883 & 137225141 & & 144.25 \\
\hline DXS984 & 137576507 & 137576708 & 145.8 & 145.8 \\
\hline GATA31E08 & 138167161 & 138167460 & & 147.38 \\
\hline DXS1205 & 138195175 & 138195518 & 147.46 & 147.46 \\
\hline DXS1227 & 138735290 & 138735546 & 150.37 & 150.37 \\
\hline DXS6751 & 138961389 & 138961667 & & 151.02 \\
\hline DXS6798 & 139563750 & 139564153 & & 152.76 \\
\hline DXS8106 & 140116944 & 140117293 & 154.35 & 154.35 \\
\hline DXS7127 & 140874035 & 140874578 & & 156.62 \\
\hline DXS6806 & 141366644 & 141366944 & 158.09 & 158.09 \\
\hline DXS8043 & 141885707 & 141885926 & & 159.62 \\
\hline MXMAFMA113ZF5 & 142386616 & 142387004 & & 161.1 \\
\hline DXS1200 & 143602429 & 143602828 & 164.69 & 164.69 \\
\hline DXS297 & 143861118 & 143861312 & & 165.05 \\
\hline DXS731 & 145029666 & 145029754 & & 166.65 \\
\hline MXMAFM323YF1 & 145482291 & 145482634 & & 167.28 \\
\hline DXS8091 & 145497860 & 145498194 & 167.3 & 167.3 \\
\hline AFM136yb10 (MXMAFM136YB10) & 146107588 & 146107837 & & 168.95 \\
\hline MXMAFMA107XF5 & 146244529 & 146244891 & & 169.32 \\
\hline DXS1193 & 146275270 & 146275535 & 169.4 & 169.4 \\
\hline DXS1123 & 146381305 & 146381484 & & 169.78 \\
\hline DXS8069 & 147408020 & 147408348 & 173.44 & 173.44 \\
\hline$\overline{D X S 8011}$ & 147637858 & 147638200 & & 176 \\
\hline DXS8103 & 147886112 & 147886447 & 178.77 & 178.77 \\
\hline AFMa225xh9 (MXMAFMA225XH9) & 148302283 & 148302628 & & 179.88 \\
\hline MXMAFMA082XA5 & 148619715 & 148620129 & & 180.74 \\
\hline DXS1073 & 151414197 & 151414518 & 188.22 & 188.22 \\
\hline
\end{tabular}

and non-parametric multipoint allele-sharing LOD scores at $1 \mathrm{cM}$ intervals along the consensus map, using the GENEHUNTER-PLUS software [61-63] implemented in common PERL scripts. These analyses were repeated using only the 964 families that were not included in the original publication of linkage to the Xq27-28 region [38]. The output files containing pedigree-specific parametric LOD scores and intermediate files for computing nonparametric Kong and Cox allele sharing LOD's for each pedigree were sent 
to the Data Coordinating Center, which then combined the data for the linkage analyses. The planned analyses were developed and approved by members of the ICPCG.

The allele frequencies for each marker in each group were estimated by counting alleles across all families, ignoring genetic relationships. All groups ran analyses using the widely-spaced genome-wide screening (GWS) markers (shown in bold text in Additional file 1: Table S1 and Table 1). Since some groups had also genotyped fine-mapping (FM) markers after finding suggestive evidence for linkage, our primary analyses used the GWS markers in order to attempt to eliminate any biases due to different information content across datasets. We also performed secondary analyses that included both GWS and FM markers. Since individual groups had finemapped at different densities and therefore obtained different levels of information content in their families, the secondary analyses were quite variable across samples in the amount of information available from the FM markers. This variability in marker density across studies could result in bias and so the combined analyses using the GWS markers are considered more reliable. We created two marker maps, one for the GWS markers and one for the FM markers (Table 1 shows the merged map of the GWS and FM markers).

A parametric model for dominant X-linked inheritance was used: the "Smith" model [3], with 2 liability classes, adapted to affecteds-only, X-linkage and a sex-limited trait. Multipoint parametric and non-parametric analyses were performed using GENEHUNTER-PLUS. After combining the results, multipoint heterogeneity LOD scores (HLODs) [63] were computed using the LOD scores from all sites. For the nonparametric allelesharing LODs, the Kong and Cox allele sharing statistics were computed using output files from GENEHUNTERPLUS [62].

\section{Results}

In the nonparametric analyses, the analysis of all families using the GWS marker set resulted in an allele-sharing LOD of 2.0 in favor of linkage to Xq27-q28 at $138 \mathrm{cM}$, which is well below the commonly accepted threshold for claiming statistically significant evidence for linkage. Non-parametric analyses using the fine mapping (FM) marker set always resulted in the same or lower allele- sharing LODs (e.g. 1.22 at $125 \mathrm{cM}$ in the complete dataset). The subsets that resulted in higher allele-sharing LODs for the GWS markers were the 732 families with $2-3$ affecteds (allele-sharing LOD $=2.56$ at $134 \mathrm{cM}$ ), the 627 families where mean age at onset was $<65$ years (allele-sharing $\mathrm{LOD}=2.34$ at $138 \mathrm{cM}$ ), and the subset of 288 families with $2-3$ affecteds that appeared to exhibit male-to-male transmission (allele-sharing $\mathrm{LOD}=3.49$ at $134 \mathrm{cM})$. The subsets of families that appeared to exhibit patterns of prostate cancer consistent with X-linked inheritance did not have high positive allele-sharing LODs (Table 2).

In the parametric, multipoint HLOD analyses, when all families were analyzed using the GWS marker set, the maximum HLOD was 1.28 at $138 \mathrm{cM}$ (Figure 1a). When the FM marker set was used, the maximum HLOD was 0.45 at $125 \mathrm{cM}$ in the complete set of families.

Subset analyses yielded larger HLOD scores in some subsets under this 2-liability class dominant parametric model. When using the GWS marker set, the subset of 104 families consistent with X-linked transmission, the 484 unclear families and the 735 non-X-linked (male-to-male transmission) families all gave positive HLODs, with a stronger signal observed in the latter group of families. When the FM marker set was used, the same pattern was observed: the subset of X-linkage transmission families gave a maximum $\mathrm{HLOD}=0.246$ at $132 \mathrm{cM}$, the unclear families gave a maximum HLOD $=0.142$ at $143 \mathrm{cM}$, and the non-X-linkage families (male-to-male transmission families) yielded a maximum HLOD $=0.62$ at $153 \mathrm{cM}$. The subset of 627 families with mean age at onset 65 years or younger gave $\mathrm{HLOD}=1.8$ at $138 \mathrm{cM}$ using the GWS markers. The 696 families with mean age greater than 65 had maximum HLOD $=0.32$ at $120 \mathrm{cM}$. Subdivisions based on the Carter criteria alone were not highly correlated with linkage evidence. Number of affected males in the family had a larger effect on linkage evidence, particularly when combined with pattern of transmission. The 732 families with 2-3 affecteds per family had maximum HLOD $=2.01$ at $134 \mathrm{cM}$, whereas the 438 families with 4-5 affected males had HLOD $=0.1$ at $168 \mathrm{cM}$ and the 153 families with 6 or more affected males had HLOD $=1.4$ at $153 \mathrm{cM}$. Consistent with the non-parametric analyses, the strongest evidence for

Table 2 Nonparametric, maximum multipoint allele-sharing LODs (location, number of families) for subsets of families

\begin{tabular}{llll}
\hline Number of affected males in family & Family consistent with X-linkage & Family unclear & Family not consistent with X-linkage \\
\hline $2-3$ & $0.26(136 \mathrm{cM}, 58)$ & $0.17(127 \mathrm{cM}, 386)$ & $\mathbf{3 . 4 9}(\mathbf{1 3 4} \mathbf{c M}, \mathbf{2 8 8})$ \\
\hline $4-5$ & $0.12(134 \mathrm{cM}, 37)$ & $0.71(83 \mathrm{cM}, 93)$ & $0.19(109 \mathrm{cM}, 308)$ \\
\hline 6 or more & $0.59(176 \mathrm{cM}, 9)$ & $0.74(109 \mathrm{cM}, 5)$ & $1.70(153 \mathrm{cM}, 139)$ \\
\hline
\end{tabular}




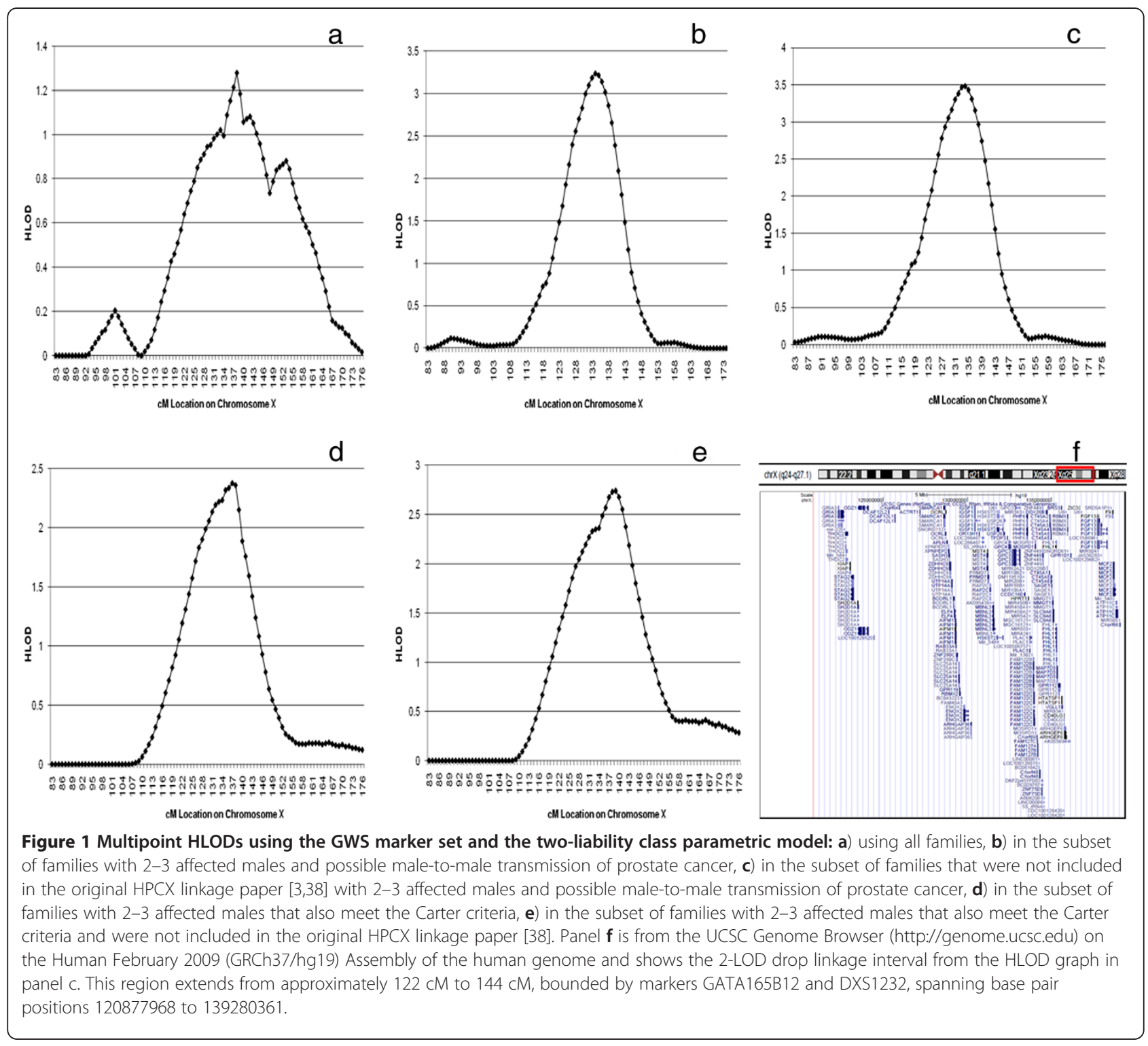

linkage occurred in the subset of 288 families with 23 affected males and at least some evidence of maleto-male transmission: maximum multipoint $\mathrm{HLOD}=$ 3.24 at $134 \mathrm{cM}$ (Figure 1b). Interestingly, when the analysis of this subset was restricted to the 248 families that were not included in the originally published linkage study [38], the maximum multipoint HLOD increased slightly to 3.47 at $134 \mathrm{cM}$, which exceeds the 3.3 value suggested by Lander and Kruglyak [64] for genome-wide significance (Figure 1c). The subset of 330 families with 2-3 affected males who also met the Carter criteria gave similarly strong linkage results with a maximum multipoint $\mathrm{HLOD}=2.38$ at $137 \mathrm{cM}$ in all such families (Figure 1d) and 2.74 at $138 \mathrm{cM}$ in the 284 families in this subset that were not included in the original X-linkage publication [38] (Figure 1e).

\section{Discussion}

In the analyses presented here, there appeared to be little distinction between families with phenotypic segregation patterns consistent with X-linked inheritance (no male-to-male transmission) or those with evidence of male-to-male transmission when considering linkage evidence provided by those subsets of families for a PC susceptibility locus at Xq27-q28. Families with smaller numbers of affected men appeared to contribute the most evidence to linkage in this region. While classification of each family based on proportion of affected men out of total men old enough to be affected might provide more homogeneous subsets, this was not feasible for this study given the many sources of families with quite different ascertainment schemes and different degrees of completeness of pedigree data collection. In addition, 
given that prostate cancer is a late age at onset disease and is quite common, we are only able to assign "unaffected" status to men who are over the age of 75 years and who have a normal digital-rectal exam and normal PSA at that advanced age. There are small numbers of such well-characterized, elderly unaffected men in this set of families and most of the families do not have any of them, which would make a proportion misleading. Families with 2-3 affecteds per family had maximum $\mathrm{HLOD}=2.01$ at $134 \mathrm{cM}$. However, the strongest suggestion of linkage was observed in both the parametric and non-parametric analyses in families with $2-3$ affecteds and possible male-to-male transmission. This pattern was observed whether we included the families from the initial linkage publication in the analysis or not. This subset of families, when excluding the families from the original linkage publication, had a multipoint HLOD of 3.47 at $134 \mathrm{cM}$. The HLOD in these new families was slightly over the Lander and Kruglyak threshold of 3.3 for genome-wide "significant" linkage but this threshold does not account for our multiple testing of different subsets, which likely requires a larger threshold to claim robust statistical evidence of linkage. However, this level of significance would meet the Lander and Kruglyak threshold for replication of a previously significant linkage $(\mathrm{p}=0.01$ or a LOD of approximately 1.0$)$ even after correction for the multiple analyses. One candidate locus, SPANXB1, lies under this linkage peak. Since prostate cancer is fairly common, our analysis models allowed for the presence of sporadic cases in the families and the families with possible male-to-male transmission included some bilineal families. Thus, it is possible that in the male-to-male transmission family subsets, some families show sharing of X-chromosome markers among the maternally-related affected relative pairs in these pedigrees and no sharing among the paternally related affected pairs, thus giving evidence for X-linkage in these families. It appears that the evidence for linkage to Xq27-q28 is being driven mainly by families not included in the original linkage study [38] and these new families have had very few FM markers genotyped in this region (Additional file 1: Table S1). Interestingly, when the FM markers were added to the analyses of these same subsets, the HLODs no longer reached the Lander and Kruglyak genome-wide significance threshold. The information content when using only the GWS markers was fairly consistent across all families. However, when the FM markers were added, the information content differed greatly across groups of families and between the original and new families. An additional difference between the original and new families is that the families from the original linkage study had no markers genotyped more centromeric than $144 \mathrm{cM}$. Thus, it is possible that the differing position of linkage peaks between the analyses of the original and new families coupled with differential linkage information across these datasets is contributing to the inconsistent results.

Our complete prostate cancer pedigree resource, with additional fine-mapping in the Xq27-28 region, provided, at best, modest suggestive evidence for linkage to this region. However, subsets of families with fewer affected individuals and paradoxically, families with some possible evidence of male-to-male disease transmission showed stronger linkage signals. This same result was observed in the analysis of very large Utah pedigrees [21], in which the best evidence for linkage was observed in the set of pedigrees with a maximum of 5 generations and an average of 2.5 genotyped prostate cancer cases. Although our finding of somewhat stronger linkage evidence in families with male-to-male disease transmission might not be sensible when considering a single locus on the $\mathrm{X}$ chromosome causing disease, this might indicate a more complex interaction between other susceptibility loci situated on the autosomes and a locus at Xq27-28. However, this finding might simply be due to high locus heterogeneity and/or important environmental risk factors in causation of prostate cancer, such that families segregating an Xlinked risk allele may have at least one affected family member who is not a carrier of this risk allele and who is paternally related to another affected family member. Figure 2 shows one such pedigree that exhibits both potential male-to-male transmission and potential maternal inheritance of PC. In this family, with a maximum LOD of 1.7 in the HPCX region, all maternally related affected males share a linked haplotype in this region and the one paternally-related affected male does not share this haplotype. Finally, it is possible that the true causal allele in this region lies within the pseudoautosomal regions PAR2, which is near this linkage peak. Since female carriers cannot become affected with prostate cancer and since no marker loci have been genotyped in the PAR2 region in our families, our current data are inadequate for resolving this.

\section{Conclusions}

Although our results do not provide strong evidence for a major prostate cancer susceptibility gene located in this region of Xq27-28, there is some evidence for a locus that may contribute to risk in families with 2-3 affecteds and in some larger families such as the one in Figure 2. This locus does not appear linked to prostate cancer risk in a high proportion of larger HPC families with many affected males. Given these observations, gene identification efforts in highly penetrant families would be better targeted to other chromosomal regions, perhaps using whole-exome or whole genome DNA sequencing techniques. Gene identification at Xq27-28 


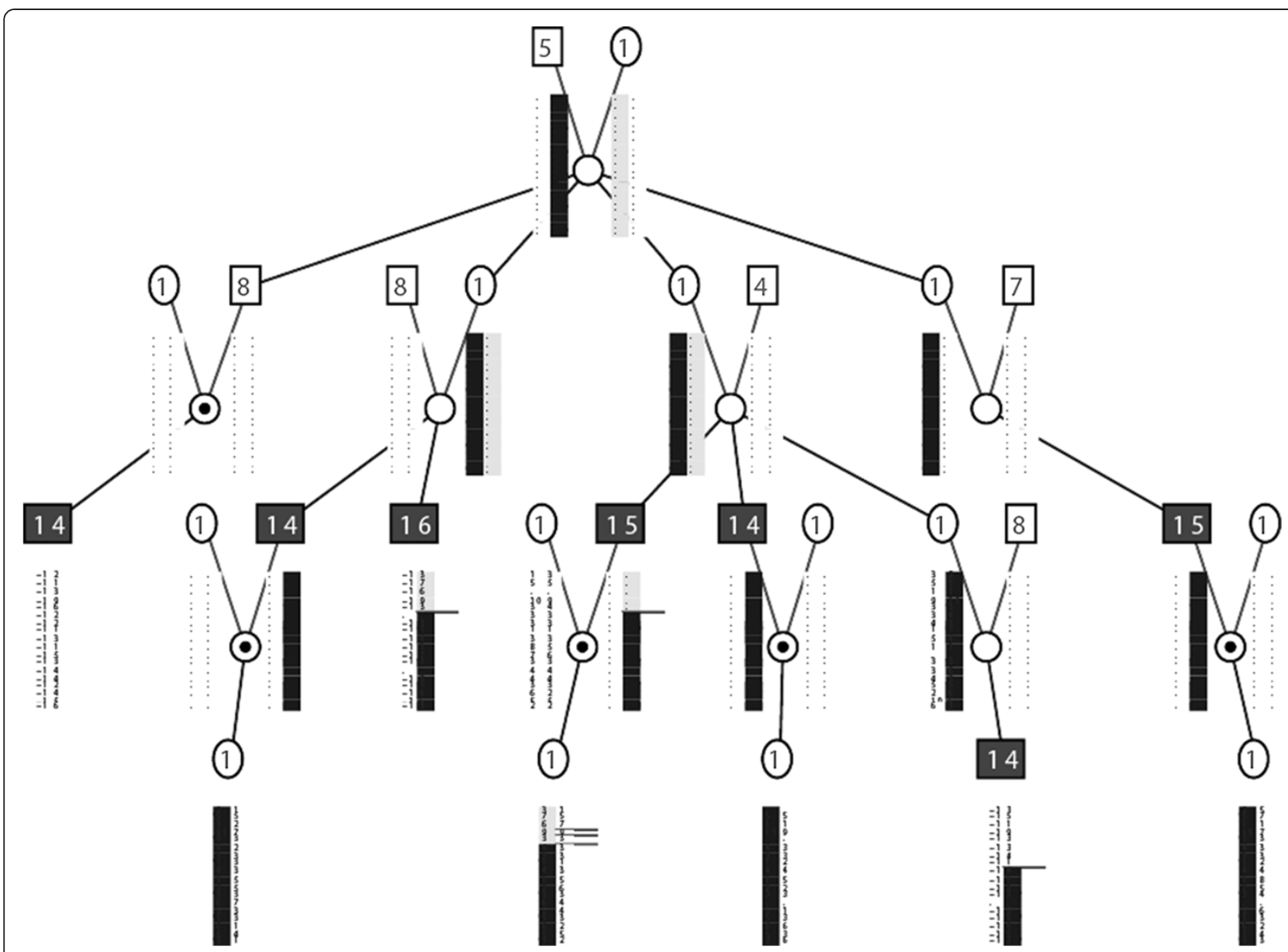

Figure 2 Pedigree that exhibits both potential male-to-male transmission and potential maternal inheritance of prostate cancer. In this family, with a maximum LOD of 1.7 in the HPCX region, all five maternally related affected males share a linked haplotype (shaded black) in this region and the one paternally-related affected male does not share this haplotype. The numbers in the shapes are liability classes based on affection status and age.

should be aimed at the families with smaller numbers of affected men identified here as belonging to the most strongly linked subset and to specific large families with strongly positive LOD scores.

\section{Additional file}

Additional file 1: Table S1. Markers genotyped and used in the linkage analyses by each data collection group [3].

\section{Competing interests}

The authors declare that they have no competing interests.

\section{Authors' contributions}

JEB-W, ELC, DJS, RE, DE, DJS, JLS, EAO, DK, LM, GGG, JLH, GS, HG, FW, ME, OC, GC-T, KAC, NJC, LAC-A, ASW, WBI and JX contributed to the design of the study. JEB-W, ELC, DJS and JX contributed to the performance of the metaanalyses. JEB-W, ELC, and CDC wrote the manuscript. DJS, SJM, RE, DE, JLS, EAO, GGG, WDF, JLH, GS, JS, TLT, GC-T, KAC, NJC, LAC-A, ASW, IO-G and WBI contributed to critical revision of the manuscript. MG, SE, JLS, EAO, DK, LM,
GGG, WDF, JLH, GS, JS, TLT, OC, LM, PM, AV, KAC, LAC-A, KEW, SDI, PCW and WBI collected and maintained samples and data. EAO, DMK, SNT, SH, SB, GC$\mathrm{T}, \mathrm{AV}, \mathrm{KAC}$ and $\mathrm{CH}$ performed or oversaw laboratory-based studies of samples. JLS, EAO, DMK, LM, SKM, CM, JH, HG, FW, GC-T, EML, NJC, JF, ASW, IO-G and MDB contributed to the linkage analyses at an ICPCG site. KD built and maintains a genotyping database at an ICPCG site. JX and LD coordinated and stored the linkage results from the contributing sites and harmonized the data. All authors have read and approved the final manuscript.

\section{Authors' information}

The members of the International Consortium for Prostate Cancer Genetics are as follows:

ACTANE Group: + Principal Investigators

UK, Sutton: S. Bullock, Q. Hope, S. Edwards, S. Bryant, S. Mulholland, S. Jugurnauth, N. Garcia, M. Guy, L. O'Brien, B. Gehr-Swain, A. Hall, R. Wilkinson, A. Ardern-Jones, D. Dearnaley, The UKGPCS Collaborators, British Association of Urological Surgeons' Section of Oncology, R. Eeles ${ }^{+}$

UK, Cambridge: Chris Evans, M. Dawn Teare, Doug Easton + (Cancer Research UK Genetic Epidemiology Unit, Strangeways Research Labs, Cambridge) Australia: John Hoppert, Graham Giles+, Dallas English, Gianluca Severi (The Cancer Council of Victoria and The University of Melbourne, Carlton, Australia) 
Canada: William D. Foulkes+, Nancy Hamel, Steven Narod, Jaques Simard+ (Department of Medical Genetics, Research Institute of the McGill University Health Centre, Montreal, Quebec; Women's College Hospital Research Institute, University of Toronto; Laboratoire de génomique des cancers, Centre de Recherche du CHUQ, Laval University, Quebec City) Texas: Mike Badzioch+, Chris Amos (MD Anderson Cancer Centre, Houston, TX and Division of Medical Genetics, University of Washington Medical Centre, Seattle, WA)

Norway, Oslo: Ketil Heimdal, Lovise Mæhle, Pål Møller + (Unit of Medical Genetics, Norwegian Radium Hospital, Oslo)

Norway, Ullevaal: Nicolai Wessel, Tone Andersen + (Dept of Oncology, Ullevaal University Hospital, Oslo)

EU Biomed: Tim Bishop+, The EU Biomed Prostate Cancer Linkage Consortium

(Cancer Research UKGenetic Epidemiology Laboratory, St James' University Hospital, Leeds, UK)

BC/CA/HI Group: Raymond N. Balise ${ }^{1}$, Richard Gallagher ${ }^{2}$, Jerry Halpern' ${ }^{1}$, Chih-lin Hsieh ${ }^{3}$, Laurence Kolonel ${ }^{4}$, Ingrid Oakley ${ }^{5}$, Dee West ${ }^{1,5}$, Alice S Whittemore ${ }^{1}$ and Anna $\mathrm{Wu}^{3}$ ('Stanford University School of Medicine, Stanford, CA; ${ }^{2}$ British Columbia Cancer Center, Vancouver; ${ }^{3}$ University of Southern California, Los Angeles, $\mathrm{CA} ;{ }^{4}$ University of Hawaii, Honolulu, HI; ${ }^{5}$ Northern California Cancer Center, Union City, CA, Stanford, CA;) CeRePP Group: Géraldine Cancel-Tassin, Antoine Valéri, Philippe Mangin, Olivier Cussenot (Centre de Recherche pour les Pathologies Prostatiques, Paris, France)

JHU Group: Kathleen E. Wiley, Sarah D. Isaacs, Marta Gielzak, Charles M. Ewing, Patrick C. Walsh, William B. Isaacs (Johns Hopkins Medical Institutions, Baltimore, MD)

Mayo Group: Daniel J. Schaid, Shannon K. McDonnell, Gerald B. Christensen, Julie M. Cunningham, Scott Hebbring, Jennifer C. Guenther, Stephen N. Thibodeau (Mayo Clinic, Rochester, MN)

Michigan Group: Ethan M. Lange', Cralen C. Davis', W. Mark Brown', Cathryn H. Bock', Kathleen A. Cooney ${ }^{2}$ ('Wake Forest University, Winston-Salem, NC; ${ }^{2}$ University of Michigan, Ann Arbor, MI)

Fred Hutchinson Cancer Research Center Group (PROGRESS): Kerry Deutsch', Danielle M. Friedrichsen², Suzanne Kolb³ ${ }^{3}$ Elaine A. Ostrander', Lee Hood', Janet L. Stanford ${ }^{3}$ ('Institute for Systems Biology, Seattle, WA; ${ }^{2}$ National Human Genome Research Institute, $\mathrm{NIH}$, Bethesda, MD; ${ }^{3}$ Division of Public Health Sciences, Fred Hutchinson Cancer Research Center, Seattle, WA) Tampere Group:Tiina Wahlfors' ${ }^{1}$ Henna Mattila', Virpi Laitinen', Riikka Nurminen', Daniel Fischer', Teuvo L.J. Tammela', Asha George', Joan BaileyWilson ${ }^{3}$, Johanna Schleutker' ('University of Tampere and Tampere University Hospital, Tampere, Finland; ${ }^{2}$ Fox Chase Cancer Center, Division of Population Science, Philadelphia, PA; ${ }^{3}$ Inherited Disease Research Branch, National Human Genome Research Institute, National Institutes of Health, Baltimore, MD

Ulm Group: Ulm Group: Sylvia Bochum', Thomas Paiss', Josef Hoegel', Florian Kurtz ${ }^{1,3}$, Manuel Luedeke ${ }^{1,2}$, Antje Rinckleb $b^{1,2}$, Kathleen Herkommer ${ }^{2,3}$, Walther Vogel ${ }^{1}$, Mark Schrader ${ }^{2}$, Christiane Maier ${ }^{1,2}$ ('Institut fuer Humangenetik, Universitätsklinikum Ulm, Ulm, Germany ${ }^{2}$ Urologische Klinik, Universitaetsklinik UIm, Ulm, Germany, ${ }^{3}$ Urologische Klinik rechts der Isar, Technische Universitaet Muenchen, Munich, Germany)

Umeå/Karolinska Group: Fredrik Wiklund, Anders Bergh, Monica Emanuelsson, Ingela Göransson, Björn-Anders Jonsson, Fredrik Lindmark, Elisabeth Stenman, Henrik Grönberg(Umeå University, Umeå, Sweden and Karolinska Institutet, Stockholm, Sweden)

Utah Group: Lisa A. Cannon-Albright, Nicola J. Camp, James M. Farnham (University of Utah, Salt Lake City, UT)

Data Coordinating Center: Jianfeng Xu, Deborah A. Meyers, Bao-Li Chang, Aubrey R. Turner, Latchezar Dimitrov, Tamara S. Adams (Center for Human Genomics, Wake Forest University School of Medicine, Winston-Salem, NC) Daniella Seminara (National Cancer Institute, Division of Cancer Control and Population Sciences, Bethesda, Maryland)

\section{Acknowledgements}

We would like to express our gratitude to the many families who participated in the many studies involved in the International Consortium for Prostate Cancer Genetics (ICPCG). The ICPCG, including the consortium's Data Coordinating Center (DCC), is made possible by a grant from the National Institutes of Health U01 CA89600 (to W.B.I.). This project was supported in part by the Intramural Research Programs of the National
Human Genome Research Institute and the National Cancer Institute, National Institutes of Health (J.E.B-W, E.L.C., C.D.C., E.A.O., D.M.K.). Additional support to participating groups, or members within groups, is as follows: ACTANE Group: Genotyping and statistical analysis for this study, and recruitment of U.K. families, was supported by Cancer Research U.K (CR-UK). Additional support was provided by The Prostate Cancer Research Foundation, The Times Christmas Appeal and the Institute of Cancer Research. Genotyping was conducted in the 'Jean Rook Gene Cloning Laboratory' which is supported by BREAKTHROUGH Breast Cancer - Charity No. 328323. The funds for the ABI 377 used in this study were generously provided by the legacy of the late Marion Silcock. We thank S. Seal and A. Hall for kindly storing and logging the samples that were provided. D.F.E is a Principal Research Fellow of CR-UK. Funding in Australia was obtained from The Cancer Council Victoria, The National Health and Medical Research Council (grants 940934, 251533, 209057, 126402, 396407), Tattersall's and The Whitten Foundation. We would like to acknowledge the work of the study coordinator M. Staples and the Research Team B. McCudden, J. Connal, R. Thorowgood, C. Costa, M. Kevan, and S. Palmer, and to J. Karpowicz for DNA extractions. The Texas study of familial prostate cancer was initiated by the Department of Epidemiology, M.D. Anderson Cancer Center. M.B. was supported by an NCl Post-doctoral Fellowship in Cancer Prevention (R25). BC/CA/HI Group: USPHS CA67044. Research carried out by WDF was supported by the Department of Defense.

Fred Hutchingson Cancer Research Center Group: USPHS CA80122 (to J.L. S.) which supports the family collection; USPHS CA78836 (to E.A.O), with additional support from the Fred Hutchinson Cancer Research Center. JHU Group: Genotyping for the JHU, University of Michigan, University of Tampere, and University of Umeå groups' pedigrees was provided by NHGRI genotyping staff including E. Gillanders, MP Jones, D. Gildea, D. Freas-Lutz, C. Markey, J. Carpten and J. Trent. Mayo Clinic Group: USPHS CA72818. Michigan Group: USPHS CA079596. University of Tampere Group: The Competitive Research Funding of the Pirkanmaa Hospital District, Reino Lahtikari Foundation, Finnish Cancer Organisations, Sigrid Juselius Foundation, and Academy of Finland grant 118413. University of UIm Group: Deutsche Krebshilfe, grant number 70-3111-V03. University of Umea Group: Work was supported by the Swedish Cancer Society and a Spear grant from the Umeå University Hospital, Umeå, Sweden. University of Utah Group: Data collection was supported by USPHS CA90752 (to L.A.C.-A.) and by the Utah Cancer Registry, which is funded by Contract HHSN261201000026C from the National Cancer Institute's Surveillance, Epidemiology, and End-Results Program with additional support from the Utah State Department of Health and the University of Utah. Partial support for all datasets within the Utah Population Database was provided by the University of Utah Huntsman Cancer Institute and also by the USPHS M01RR00064 from the National Center for Research Resources. Genotyping services were provided by the Center for Inherited Disease Research (N01HG-65403). CeRePP Group: work was supported by the Association pour la Recherche sur le Cancer, grant number 5441. DCC: The study is partially supported by USPHS CA106523 (to J.X.), USPHS CA95052 (to J.X.), and Department of Defense grant PC051264 (to J.X.).

The funding bodies did not play a role in study design, in the collection, analysis, and interpretation of data, in the writing of the manuscript or in the decision to submit the manuscript for publication.

\section{Author details}

${ }^{1}$ Inherited Disease Research Branch, National Human Genome Research Institute, National Institutes of Health, Baltimore MD 21224, USA. ${ }^{2}$ Johns Hopkins Bloomberg School of Public Health, Baltimore MD, USA. ${ }^{3}$ Department of Health Sciences Research, Mayo Clinic, Rochester MN 55905, USA. ${ }^{4}$ Data Coordinating Center for the ICPCG and Center for Human Genomics, Wake Forest University School of Medicine, Winston-Salem NC 27157, USA. ${ }^{5}$ University of Utah ICPCG Group and Division of Genetic Epidemiology, University of Utah School of Medicine, Salt Lake City UT, USA. ${ }^{6}$ George E. Wahlen Department of Veterans Affairs Medical Center, Salt Lake City UT, USA. ${ }^{7}$ African American Hereditary Prostate Cancer ICPCG Group, Phoenix AZ, USA. ${ }^{8}$ Fox Chase Cancer Center, Philadelphia PA, USA. ${ }^{9}$ Karmanos Cancer Institute, Wayne State University, Detroit MI, USA. ${ }^{10}$ Translational Genomics Research Institute, Genetic Basis of Human Disease Research Division, Phoenix AZ, USA. ${ }^{11}$ ACTANE consortium. ${ }^{12}$ Cancer Epidemiology Centre, Cancer Council Victoria, Melbourne Australia. ${ }^{13}$ Centre for Molecular, Environmental, Genetic and Analytic Epidemiology, School of 
Population Health, The University of Melbourne, Melbourne Australia. ${ }^{14}$ Program in Cancer Genetics, McGill University, Montreal QC, Canada. ${ }^{15}$ Department of Medical Genetics, Oslo University Hospital, The Norwegian Radium Hospital, Oslo, Norway. ${ }^{16}$ Institute of Cancer Research and Royal Marsden NHS Foundation Trust, Surrey UK. ${ }^{17}$ Cancer Research UK Genetic Epidemiology Unit, Cambridge UK. ${ }^{18}$ Division of Medical Genetics, University of Washington Medical Center, Seattle WA, USA. ${ }^{19} \mathrm{BC} / \mathrm{CA} / \mathrm{HI}$ ICPCG Group, Stanford CA, USA. ${ }^{20}$ Department of Health Research and Policy, Stanford School of Medicine, Stanford CA, USA. ${ }^{21}$ Stanford Cancer Institute, Stanford School of Medicine, Stanford CA, USA. ${ }^{22}$ Department of Urology and Department of Biochemistry and Molecular Biology, University of Southern California, Los Ageles CA, USA. ${ }^{23}$ FHCRC ICPCG Group, Seattle WA, USA.

${ }^{24}$ Fred Hutchinson Cancer Research Center, Division of Public Health Sciences, Seattle WA, USA. ${ }^{25}$ Cancer Genetics Branch, National Human Genome Research Institute, National Institutes of Health, Bethesda MD, USA ${ }^{26}$ Institute for Systems Biology, Seattle WA, USA. ${ }^{27}$ Johns Hopkins University ICPCG Group and Department of Urology, Johns Hopkins Medical Institutions, Baltimore MD, USA. ${ }^{28}$ Mayo Clinic, Rochester MN, USA. ${ }^{29}$ University of Michigan ICPCG Group, Ann Arbor MI, USA. ${ }^{30}$ Department of Genetics, University of North Carolina, Chapel Hill NC, USA. ${ }^{31}$ University of Michigan, Ann Arbor MI, USA. ${ }^{32}$ University of Tampere ICPCG Group, Tampere Finland. ${ }^{33}$ Institute of Biomedical Technology, University of Tampere, Tampere Finland. ${ }^{34}$ Centre for Laboratory Medicine and Department of Urology, Tampere University Hospital, Tampere Finland. ${ }^{35}$ University of UIm ICPCG Group, Ulm Germany. ${ }^{36}$ Dept of Urology, University of UIm, UIm Germany. ${ }^{37}$ Institute of Human Genetics, University of Ulm, Ulm Germany. ${ }^{38}$ Department of Medical Epidemiology and Biostatistics, Karolinska Institutet, Stockholm Sweden. ${ }^{39}$ Oncologic Centre, Umeå University, Umeå Sweden. ${ }^{40}$ CeRePP ICPCG Group, 75020 Paris France. ${ }^{41}$ Hopital Tenon, Assistance Publique-Hopitaux de Paris, 75020 Paris France.

${ }^{42}$ Cancer Prevention Institute of California.

Received: 26 July 2011 Accepted: 30 April 2012

Published: 19 June 2012

\section{References}

1. Nelson WG, De Marzo AM, Isaacs WB: Prostate cancer. N Engl J Med 2003, 349(4):366-381.

2. Jemal A, Siegel R, Xu J, Ward E: Cancer statistics, 2010. CA Cancer J Clin 2010, 60(5):277-300

3. Smith JR, Freije D, Carpten JD, Gronberg H, Xu J, Isaacs SD, Brownstein MJ, Bova GS, Guo H, Bujnovszky P, Nusskern DR, Damber JE, Bergh A, Emanuelsson M, Kallioniemi OP, Walker-Daniels J, Bailey-Wilson JE, Beaty TH, Meyers DA, Walsh PC, Collins FS, Trent JM, Isaacs WB: Major susceptibility locus for prostate cancer on chromosome 1 suggested by a genomewide search. Science 1996, 274(5291):1371-1374.

4. $\mathrm{Xu} \mathrm{J:} \mathrm{Combined} \mathrm{analysis} \mathrm{of} \mathrm{hereditary} \mathrm{prostate} \mathrm{cancer} \mathrm{linkage} \mathrm{to}$ 1q24-25: results from 772 hereditary prostate cancer families from the International Consortium for Prostate Cancer Genetics. Am J Hum Genet 2000, 66(3):945-957

5. Carpten J, Nupponen N, Isaacs S, Sood R, Robbins C, Xu J, Faruque M, Moses T, Ewing C, Gillanders E, Hu P, Bujnovszky P, Makalowska I, BaffoeBonnie A, Faith D, Smith J, Stephan D, Wiley K, Brownstein M, Gildea D, Kelly B, Jenkins R, Hostetter G, Matikainen M, Schleutker J, Klinger K, Connors T, Xiang Y, Wang Z, De Marzo A, Papadopoulos N, Kallioniemi OP, Burk R, Meyers D, Gronberg H, Meltzer P, Silverman R, Bailey-Wilson J, Walsh $P$, Isaacs $W$, Trent J: Germline mutations in the ribonuclease $L$ gene in families showing linkage with HPC1. Nat Genet 2002, 30(2):181-184

6. Agalliu I, Leanza SM, Smith L, Trent JM, Carpten JD, Bailey-Wilson JE, Burk RD: Contribution of HPC1 (RNASEL) and HPCX variants to prostate cancer in a founder population. Prostate 2010, 70(15):1716-1727.

7. Meyer MS, Penney KL, Stark JR, Schumacher FR, Sesso HD, Loda M Fiorentino M, Finn S, Flavin RJ, Kurth T, Price AL, Giovannucci EL, Fall K, Stampfer MJ, Ma J, Mucci LA: Genetic variation in RNASEL associated with prostate cancer risk and progression. Carcinogenesis 2010, 31(9):1597-1603.

8. Fesinmeyer MD, Kwon EM, Fu R, Ostrander EA, Stanford JL: Genetic variation in RNASEL and risk for prostate cancer in a population-based case-control study. Prostate 2011, 71(14):1538-1547. doi:10.1002/ pros. 21370 .
9. Mi YY, Zhu LJ, Wu S, Feng NH: An update analysis of two polymorphisms in encoding ribonuclease $L$ gene and prostate cancer risk: involving 13,372 cases and 11,953 controls. Genes Nutr 2011, 6(4):397-402.

10. Wei B, Xu Z, Ruan J, Zhu M, Jin K, Zhou D, Yan Z, Xuan F, Zhou H, Huang X, Zhang J, Lu P, Shao J: RNASEL Asp541Glu and Arg462Gln polymorphisms in prostate cancer risk: evidences from a meta-analysis. Mol Biol Rep 2012, 39(3):2347-2353

11. Baffoe-Bonnie AB, Smith JR, Stephan DA, Schleutker J, Carpten JD, Kainu T, Gillanders EM, Matikainen M, Teslovich TM, Tammela T, Sood R, Balshem AM, Scarborough SD, Xu J, Isaacs WB, Trent JM, Kallioniemi OP, BaileyWilson JE: A major locus for hereditary prostate cancer in Finland: localization by linkage disequilibrium of a haplotype in the HPCX region. Hum Genet 2005, 117(4):307-316

12. Bergthorsson JT, Johannesdottir G, Arason A, Benediktsdottir KR, Agnarsson BA, Bailey-Wilson JE, Gillanders E, Smith J, Trent J, Barkardottir RB: Analysis of $\mathrm{HPC1}, \mathrm{HPCX}$, and PCaP in Icelandic hereditary prostate cancer. Hum Genet 2000, 107(4):372-375.

13. Berry R, Schaid DJ, Smith JR, French AJ, Schroeder JJ, McDonnell SK, Peterson BJ, Wang ZY, Carpten JD, Roberts SG, Tester DJ, Blute ML, Trent JM, Thibodeau SN: Linkage analyses at the chromosome 1 loci 1q24-25 (HPC1), 1q42.2-43 (PCAP), and 1p36 (CAPB) in families with hereditary prostate cancer. Am J Hum Genet 2000, 66(2):539-546.

14. Berry R, Schroeder JJ, French AJ, McDonnell SK, Peterson BJ, Cunningham JM, Thibodeau SN, Schaid DJ: Evidence for a prostate cancer-susceptibility locus on chromosome 20. Am J Hum Genet 2000, 67(1):82-91.

15. Berthon P, Valeri A, Cohen-Akenine A, Drelon E, Paiss T, Wohr G, Latil A, Millasseau P, Mellah I, Cohen N, Blanche H, Bellane-Chantelot C, Demenais F, Teillac P, Le Duc A, de Petriconi R, Hautmann R, Chumakov I, Bachner L, Maitland NJ, Lidereau R, Vogel W, Fournier G, Mangin P, Cussenot O, et al: Predisposing gene for early-onset prostate cancer, localized on chromosome 1q42.2-43. Am J Hum Genet 1998, 62(6):1416-1424.

16. Bock CH, Cunningham JM, McDonnell SK, Schaid DJ, Peterson BJ, Pavlic RJ, Schroeder JJ, Klein J, French AJ, Marks A, Thibodeau SN, Lange EM, Cooney KA: Analysis of the prostate cancer-susceptibility locus HPC20 in 172 families affected by prostate cancer. Am J Hum Genet 2001, 68(3):795-801.

17. Cancel-Tassin G, Latil A, Valeri A, Guillaume E, Mangin P, Fournier G, Berthon $\mathrm{P}$, Cussenot O: No evidence of linkage to HPC20 on chromosome 20q13 in hereditary prostate cancer. Int J Cancer 2001, 93(3):455-456.

18. Cancel-Tassin G, Latil A, Valeri A, Mangin P, Fournier G, Berthon P, Cussenot $\mathrm{O}: \mathrm{PCAP}$ is the major known prostate cancer predisposing locus in families from south and west Europe. Eur J Hum Genet 2001, 9(2):135-142.

19. Cunningham JM, McDonnell SK, Marks A, Hebbring S, Anderson SA, Peterson BJ, Slager S, French A, Blute ML, Schaid DJ, Thibodeau SN: Genome linkage screen for prostate cancer susceptibility loci: results from the Mayo Clinic Familial Prostate Cancer Study. Prostate 2003, 57(4):335-346.

20. Edwards S, Meitz J, Eles R, Evans C, Easton D, Hopper J, Giles G, Foulkes WD, Narod S, Simard J, Badzioch M, Mahle L: Results of a genome-wide linkage analysis in prostate cancer families ascertained through the ACTANE consortium. Prostate 2003, 57(4):270-279.

21. Farnham JM, Camp NJ, Swensen J, Tavtigian SV, Albright LA: Confirmation of the HPCX prostate cancer predisposition locus in large Utah prostate cancer pedigrees. Hum Genet 2005, 116(3):179-185.

22. Friedrichsen DM, Stanford JL, Isaacs SD, Janer M, Chang BL, Deutsch K, Gillanders E, Kolb S, Wiley KE, Badzioch MD, Zheng SL, Walsh PC, Jarvik GP, Hood L, Trent JM, Isaacs WB, Ostrander EA, Xu J: Identification of a prostate cancer susceptibility locus on chromosome 7q11-21 in Jewish families. Proc Natl Acad Sci U S A 2004, 101(7):1939-1944.

23. Gibbs M, Stanford JL, McIndoe RA, Jarvik GP, Kolb S, Goode EL, Chakrabarti L, Schuster EF, Buckley VA, Miller EL, Brandzel S, Li S, Hood L, Ostrander EA: Evidence for a rare prostate cancer-susceptibility locus at chromosome 1p36. Am J Hum Genet 1999, 64(3):776-787.

24. Hsieh CL, Oakley-Girvan I, Balise RR, Halpern J, Gallagher RP, Wu AH, Kolonel LN, O'Brien LE, Lin IG, Van Den Berg DJ, Teh CZ, West DW, Whittemore AS: A genome screen of families with multiple cases of prostate cancer: evidence of genetic heterogeneity. Am J Hum Genet 2001, 69(1):148-158.

25. Janer M, Friedrichsen DM, Stanford JL, Badzioch MD, Kolb S, Deutsch K, Peters MA, Goode EL, Welti R, DeFrance HB, Iwasaki L, Li S, Hood L, 
Ostrander EA, Jarvik GP: Genomic scan of 254 hereditary prostate cancer families. Prostate 2003, 57(4):309-319.

26. Johns LE, Houlston RS: A systematic review and meta-analysis of familial prostate cancer risk. BJU Int 2003, 91(9):789-794.

27. Mclndoe RA, Stanford JL, Gibbs M, Jarvik GP, Brandzel S, Neal CL, Li S, Gammack JT, Gay AA, Goode EL, Hood L, Ostrander EA: Linkage analysis of 49 high-risk families does not support a common familial prostate cancer-susceptibility gene at 1q24-25. Am J Hum Genet 1997, 61(2):347-353

28. Neville PJ, Conti DV, Krumroy LM, Catalona WJ, Suarez BK, Witte JS, Casey G: Prostate cancer aggressiveness locus on chromosome segment 19q12-q13.1 identified by linkage and allelic imbalance studies. Genes Chromosomes Cancer 2003, 36(4):332-339.

29. Neville PJ, Conti DV, Paris PL, Levin H, Catalona WJ, Suarez BK, Witte JS, Casey G: Prostate cancer aggressiveness locus on chromosome 7q32-q33 identified by linkage and allelic imbalance studies. Neoplasia 2002, 4(5):424-431.

30. Ostrander EA, Stanford JL: Genetics of prostate cancer: too many loci, too few genes. Am J Hum Genet 2000, 67(6):1367-1375.

31. Paiss T, Worner S, Kurtz F, Haeussler J, Hautmann RE, Gschwend JE, Herkommer K, Vogel W: Linkage of aggressive prostate cancer to chromosome 7q31-33 in German prostate cancer families. Eur J Hum Genet 2003, 11(1):17-22.

32. Schleutker J, Baffoe-Bonnie AB, Gillanders E, Kainu T, Jones MP, Freas-Lutz D, Markey C, Gildea D, Riedesel E, Albertus J, Gibbs KD Jr, Matikainen M, Koivisto PA, Tammela T, Bailey-Wilson JE, Trent JM, Kallioniemi OP: Genomewide scan for linkage in finnish hereditary prostate cancer (HPC) families identifies novel susceptibility loci at 11q14 and 3p25-26. Prostate 2003, 57(4):280-289.

33. Schleutker J, Matikainen M, Smith J, Koivisto P, Baffoe-Bonnie A, Kainu T, Gillanders E, Sankila R, Pukkala E, Carpten J, Stephan D, Tammela T, Brownstein M, Bailey-Wilson J, Trent J, Kallioniemi OP: A genetic epidemiological study of hereditary prostate cancer (HPC) in Finland: frequent HPCX linkage in families with late-onset disease. Clin Cancer Res 2000, 6(12):4810-4815.

34. Slager SL, Schaid DJ, Cunningham JM, McDonnell SK, Marks AF, Peterson BJ, Hebbring SJ, Anderson S, French AJ, Thibodeau SN: Confirmation of linkage of prostate cancer aggressiveness with chromosome 19q. Am J Hum Genet 2003, 72(3):759-762.

35. Tavtigian SV, Simard J, Teng DH, Abtin V, Baumgard M, Beck A, Camp NJ, Carillo AR, Chen Y, Dayananth P, Desrochers M, Dumont M, Farnham JM, Frank D, Frye C, Ghaffari S, Gupte JS, Hu R, lliev D, Janecki T, Kort EN, Laity KE, Leavitt A, Leblanc G, McArthur-Morrison J, Pederson A, Penn B, Peterson KT, Reid JE, Richards S, Schroeder M, Smith R, Snyder SC, Swedlund B, Swensen J, Thomas A, Tranchant M, Woodland AM, Labrie F, Skolnick MH, Neuhausen S, Rommens J, Cannon-Albright LA: A candidate prostate cancer susceptibility gene at chromosome 17p. Nat Genet 2001, 27 (2):172-180.

36. Witte JS, Goddard KA, Conti DV, Elston RC, Lin J, Suarez BK, Broman KW, Burmester JK, Weber JL, Catalona WJ: Genomewide scan for prostate cancer-aggressiveness loci. Am J Hum Genet 2000, 67(1):92-99.

37. Xu J, Gillanders EM, Isaacs SD, Chang BL, Wiley KE, Zheng SL, Jones M, Gildea D, Riedesel E, Albertus J, Freas-Lutz D, Markey C, Meyers DA, Walsh PC, Trent JM, Isaacs WB: Genome-wide scan for prostate cancer susceptibility genes in the Johns Hopkins hereditary prostate cancer families. Prostate 2003, 57(4):320-325.

38. Xu J, Meyers D, Freije D, Isaacs S, Wiley K, Nusskern D, Ewing C, Wilkens E, Bujnovszky P, Bova GS, Walsh P, Isaacs W, Schleutker J, Matikainen M, Tammela T, Visakorpi T, Kallioniemi OP, Berry R, Schaid D, French A, McDonnell S, Schroeder J, Blute M, Thibodeau S, Gronberg H, Emanuelsson M, Damber JE, Bergh A, Jonsson BA, Smith J, Bailey-Wilson J, Carpten J, Stephan D, Gillanders E, Amundson I, Kainu T, Freas-Lutz D, Baffoe-Bonnie A, Van Aucken A, Sood R, Collins F, Brownstein M, Trent J: Evidence for a prostate cancer susceptibility locus on the X chromosome. Nat Genet 1998, 20(2):175-179.

39. Xu J, Zheng SL, Hawkins GA, Faith DA, Kelly B, Isaacs SD, Wiley KE, Chang B, Ewing CM, Bujnovszky P, Carpten JD, Bleecker ER, Walsh PC, Trent JM, Meyers DA, Isaacs WB: Linkage and association studies of prostate cancer susceptibility: evidence for linkage at 8p22-23. Am J Hum Genet 2001, 69(2):341-350
40. Zheng SL, Xu J, Isaacs SD, Wiley K, Chang B, Bleecker ER, Walsh PC, Trent $J M$, Meyers DA, Isaacs WB: Evidence for a prostate cancer linkage to chromosome 20 in 159 hereditary prostate cancer families. Hum Genet 2001, 108(5):430-435.

41. Easton DF, Schaid DJ, Whittemore AS, Isaacs WJ: Where are the prostate cancer genes?-A summary of eight genome wide searches. Prostate 2003, 57(4):261-269.

42. Schaid DJ: The complex genetic epidemiology of prostate cancer. Hum Mol Genet 2004, 13(1):R103-R121.

43. Thomas G, Jacobs KB, Yeager M, Kraft P, Wacholder S, Orr N, Yu K, Chatterjee N, Welch R, Hutchinson A, Crenshaw A, Cancel-Tassin G, Staats BJ, Wang Z, Gonzalez-Bosquet J, Fang J, Deng X, Berndt SI, Calle EE, Feigelson HS, Thun MJ, Rodriguez C, Albanes D, Virtamo J, Weinstein S, Schumacher FR, Giovannucci E, Willett WC, Cussenot O, Valeri A, Andriole GL, Crawford ED, Tucker M, Gerhard DS, Fraumeni JF Jr, Hoover R, Hayes RB, Hunter DJ, Chanock SJ: Multiple loci identified in a genome-wide association study of prostate cancer. Nat Genet 2008, 40(3):310-315.

44. Yeager M, Orr N, Hayes RB, Jacobs KB, Kraft P, Wacholder S, Minichiello MJ, Fearnhead P, Yu K, Chatterjee N, Wang Z, Welch R, Staats BJ, Calle EE, Feigelson HS, Thun MJ, Rodriguez C, Albanes D, Virtamo J, Weinstein S, Schumacher FR, Giovannucci E, Willett WC, Cancel-Tassin G, Cussenot O, Valeri A, Andriole GL, Gelmann EP, Tucker M, Gerhard DS, Fraumeni JF Jr, Hoover R, Hunter DJ, Chanock SJ, Thomas G: Genome-wide association study of prostate cancer identifies a second risk locus at 8q24. Nat Genet 2007, 39(5):645-649.

45. Gudmundsson J, Sulem P, Manolescu A, Amundadottir LT, Gudbjartsson D, Helgason A, Rafnar T, Bergthorsson JT, Agnarsson BA, Baker A, Sigurdsson A, Benediktsdottir KR, Jakobsdottir M, Xu J, Blondal T, Kostic J, Sun J, Ghosh S, Stacey SN, Mouy M, Saemundsdottir J, Backman VM, Kristjansson K, Tres A, Partin AW, Albers-Akkers MT, Godino-Ivan Marcos J, Walsh PC, Swinkels DW, Navarrete S, Isaacs SD, Aben KK, Graif T, Cashy J, Ruiz-Echarri M, Wiley KE, Suarez BK, Witjes JA, Frigge M, Ober C, Jonsson E, Einarsson GV, Mayordomo Jl, Kiemeney LA, Isaacs WB, Catalona WJ, Barkardottir RB, Gulcher JR, Thorsteinsdottir U, Kong A, Stefansson K: Genome-wide association study identifies a second prostate cancer susceptibility variant at $8 q 24$. Nat Genet 2007, 39(5):631-637.

46. Easton DF, Eeles RA: Genome-wide association studies in cancer. Hum Mol Genet 2008, 17(R2):R109-R115.

47. Eeles RA, Kote-Jarai Z, Giles GG, Olama AA, Guy M, Jugurnauth SK, Mulholland S, Leongamornlert DA, Edwards SM, Morrison J, Field HI, Southey MC, Severi G, Donovan JL, Hamdy FC, Dearnaley DP, Muir KR, Smith C, Bagnato M, Ardern-Jones AT, Hall AL, O'Brien LT, Gehr-Swain BN, Wilkinson RA, Cox A, Lewis S, Brown PM, Jhavar SG, Tymrakiewicz M, Lophatananon A, Bryant SL, Horwich A, Huddart RA, Khoo VS, Parker CC, Woodhouse CJ, Thompson A, Christmas T, Ogden C, Fisher C, Jamieson C, Cooper CS, English DR, Hopper JL, Neal DE, Easton DF: Multiple newly identified loci associated with prostate cancer susceptibility. Nat Genet 2008, 40(3):316-321.

48. Gudmundsson J, Sulem P, Gudbjartsson DF, Blondal T, Gylfason A, Agnarsson BA, Benediktsdottir KR, Magnusdottir DN, Orlygsdottir G, Jakobsdottir M, Stacey SN, Sigurdsson A, Wahlfors T, Tammela T, Breyer JP, McReynolds KM, Bradley KM, Saez B, Godino J, Navarrete S, Fuertes F, Murillo L, Polo E, Aben KK, van Oort IM, Suarez BK, Helfand BT, Kan D, Zanon C, Frigge ML, Kristjansson K, Gulcher JR, Einarsson GV, Jonsson E, Catalona WJ, Mayordomo Jl, Kiemeney LA, Smith JR, Schleutker J, Barkardottir RB, Kong A, Thorsteinsdottir U, Rafnar T, Stefansson K: Genome-wide association and replication studies identify four variants associated with prostate cancer susceptibility. Nat Genet 2009, 41(10):1122-1126.

49. Eeles RA, Kote-Jarai Z, Al Olama AA, Giles GG, Guy M, Severi G, Muir K, Hopper JL, Henderson BE, Haiman CA, Schleutker J, Hamdy FC, Neal DE, Donovan JL, Stanford JL, Ostrander EA, Ingles SA, John EM, Thibodeau SN, Schaid D, Park JY, Spurdle A, Clements J, Dickinson JL, Maier C, Vogel W, Dork T, Rebbeck TR, Cooney KA, Cannon-Albright L, Chappuis PO, Hutter P, Zeegers M, Kaneva R, Zhang HW, Lu YJ, Foulkes WD, English DR, Leongamornlert DA, Tymrakiewicz M, Morrison J, Ardern-Jones AT, Hall AL, O'Brien LT, Wilkinson RA, Saunders EJ, Page EC, Sawyer EJ, Edwards SM, Dearnaley DP, Horwich A, Huddart RA, Khoo VS, Parker CC, Van As N, Woodhouse CJ, Thompson A, Christmas T, Ogden C, Cooper CS, Southey MC, Lophatananon A, Liu JF, Kolonel LN, Le Marchand L, Wahlfors T, Tammela TL, Auvinen A, Lewis SJ, Cox A, FitzGerald LM, Koopmeiners JS, Karyadi DM, Kwon EM, Stern MC, Corral R, Joshi AD, Shahabi A, McDonnell 
SK, Sellers TA, Pow-Sang J, Chambers S, Aitken J, Gardiner RA, Batra J, Kedda MA, Lose F, Polanowski A, Patterson B, Serth J, Meyer A, Luedeke M, Stefflova K, Ray AM, Lange EM, Farnham J, Khan H, Slavov C, Mitkova A, Cao G, Easton DF: Identification of seven new prostate cancer susceptibility loci through a genome-wide association study. Nat Genet 2009, 41(10):1116-1121.

50. Varghese JS, Easton DF: Genome-wide association studies in common cancers-what have we learnt? Curr Opin Genet Dev 2010, 20(3):201-209.

51. Bochum S, Paiss T, Vogel W, Herkommer K, Hautmann R, Haeussler J: Confirmation of the prostate cancer susceptibility locus HPCX in a set of 104 German prostate cancer families. Prostate 2002, 52(1):12-19.

52. Peters MA, Jarvik GP, Janer M, Chakrabarti L, Kolb S, Goode EL, Gibbs M, DuBois CC, Schuster EF, Hood L, Ostrander EA, Stanford JL: Genetic linkage analysis of prostate cancer families to Xq27-28. Hum Hered 2001, 51(1-2):107-113.

53. Lange EM, Chen H, Brierley K, Perrone EE, Bock CH, Gillanders E, Ray ME, Cooney KA: Linkage analysis of 153 prostate cancer families over a 30-CM region containing the putative susceptibility locus HPCX. Clin Cancer Res 1999, 5(12):4013-4020.

54. Kouprina N, Pavlicek A, Noskov VN, Solomon G, Otstot J, Isaacs W, Carpten JD, Trent JM, Schleutker J, Barrett JC, Jurka J, Larionov V: Dynamic structure of the SPANX gene cluster mapped to the prostate cancer susceptibility locus HPCX at Xq27. Genome Res 2005, 15(11):1477-1486.

55. Kouprina N, Noskov VN, Solomon G, Otstot J, Isaacs W, Xu J, Schleutker J, Larionov V: Mutational analysis of SPANX genes in families with X-linked prostate cancer. Prostate 2007, 67(8):820-828.

56. Gudmundsson J, Sulem P, Rafnar T, Bergthorsson JT, Manolescu A, Gudbjartsson D, Agnarsson BA, Sigurdsson A, Benediktsdottir KR, Blondal T, Jakobsdottir M, Stacey SN, Kostic J, Kristinsson KT, Birgisdottir B, Ghosh S, Magnusdottir DN, Thorlacius S, Thorleifsson G, Zheng SL, Sun J, Chang BL, Elmore JB, Breyer JP, McReynolds KM, Bradley KM, Yaspan BL, Wiklund F, Stattin P, Lindstrom S, Adami HO, McDonnell SK, Schaid DJ, Cunningham JM, Wang L, Cerhan JR, St Sauver JL, Isaacs SD, Wiley KE, Partin AW, Walsh PC, Polo S, Ruiz-Echarri M, Navarrete S, Fuertes F, Saez B, Godino J, Weijerman PC, Swinkels DW, Aben KK, Witjes JA, Suarez BK, Helfand BT, Frigge ML, Kristjansson K, Ober C, Jonsson E, Einarsson GV, Xu J, Gronberg H, Smith JR, Thibodeau SN, Isaacs WB, Catalona WJ, Mayordomo JI, Kiemeney LA, Barkardottir RB, Gulcher JR, Thorsteinsdottir U, Kong A, Stefansson $\mathrm{K}$ : Common sequence variants on $2 \mathrm{p} 15$ and $\mathrm{Xp} 11.22$ confer susceptibility to prostate cancer. Nat Genet 2008, 40(3):281-283.

57. Carter BS, Beaty TH, Steinberg GD, Childs B, Walsh PC: Mendelian inheritance of familial prostate cancer. Proc Natl Acad Sci U S A 1992, 89(8):3367-3371.

58. Carter BS, Bova GS, Beaty TH, Steinberg GD, Childs B, Isaacs WB, Walsh PC: Hereditary prostate cancer: epidemiologic and clinical features. $J$ Urol 1993, 150(3):797-802.

59. Schaid DJ, Chang BL: Description of the International Consortium For Prostate Cancer Genetics, and failure to replicate linkage of hereditary prostate cancer to 20q13. Prostate 2005, 63(3):276-290.

60. Kong A, Gudbjartsson DF, Sainz J, Jonsdottir GM, Gudjonsson SA, Richardsson B, Sigurdardottir S, Barnard J, Hallbeck B, Masson G, Shlien A, Palsson ST, Frigge ML, Thorgeirsson TE, Gulcher JR, Stefansson K:

A high-resolution recombination map of the human genome. Nat Genet 2002, 31(3):241-247.

61. Kong A, Cox NJ: Allele-sharing models: LOD scores and accurate linkage tests. Am J Hum Genet 1997, 61(5):1179-1188.

62. Kruglyak L, Daly MJ, Reeve-Daly MP, Lander ES: Parametric and nonparametric linkage analysis: a unified multipoint approach. Am J Hum Genet 1996, 58(6):1347-1363.

63. Ott J: Analysis of Human Genetic Linkage. Baltimore: The Johns Hopkins University Press; 1999.

64. Lander E, Kruglyak L: Genetic dissection of complex traits: guidelines for interpreting and reporting linkage results. Nat Genet 1995, 11(3):241-247.

doi:10.1186/1471-2350-13-46

Cite this article as: Bailey-Wilson et al:: Analysis of Xq27-28 linkage in the international consortium for prostate cancer genetics (ICPCG) families. BMC Medical Genetics 2012 13:46.

\section{Submit your next manuscript to BioMed Central and take full advantage of:}

- Convenient online submission

- Thorough peer review

- No space constraints or color figure charges

- Immediate publication on acceptance

- Inclusion in PubMed, CAS, Scopus and Google Scholar

- Research which is freely available for redistribution 